\title{
The Cultural Importance of Diachronic Analysis of Literary Texts in Relation to Teaching Arabic as a Foreign Language: Sexuality and Gender in The Ring of the Dove
}

\author{
Borjan Grozdanoski. University American College Skopje. Skopje, Republic North Macedonia \\ Raúl Ruiz Cecilia. Universidad de Granada. España - ORCID 0000-0002-8119-549X
}

\section{Recepción: 16/02/2019 | Aceptado: 19/04/2019}

Correspondencia a través de ORCID: Borjan Grozdanoski

0000-0002-1233-1662

Citar: Grozdanoski, B. \& Ruiz Cecilia, R. (2019). The Cultural Importance of Diachronic Analysis of Literary Texts in Relation to Teaching Arabic as a Foreign Language: Sexuality and Gender in The Ring of the Dove. ReiDoCrea - Monográfico sobre Perspectivas transnacionales en la enseñanza de lenguas, 8(3), 305-323.

Resumen: Esta investigación surgió de la necesidad de reflexionar sobre temas relacionados con el género, especialmente en relación con la teoría Queer, la inversión y la polarización de género, en El Collar de la paloma de Ibn Hazm de Córdoba. El objetivo de este estudio es ofrecer perspectivas más amplias en la enseñanza del árabe, con énfasis en la importancia de la conciencia cultural con respecto a las cuestiones relacionadas con el sexo y el género. La metodología aplicada en la investigación consiste en análisis literario selectivo, comparación, yuxtaposición y contraste de hallazgos previos sobre el tema contrastando el texto principal en diferentes versiones. Como resultado de nuestra investigación, podemos reafirmar algunos hallazgos ya establecidos y también contribuir con nuevos sobre la autonomía sexual presentados en el tratado. En conclusión, hasta cierto punto, El collar de la paloma está liberado de las cadenas dogmáticas medievales con respecto a la sexualidad y la afiliación de género.

Palabras clave: sexualidad, genero

La importancia cultural del análisis diacrónico de textos literarios en relación con la enseñanza del árabe como lengua extranjera: la sexualidad y el género en el Collar de la paloma

\begin{abstract}
This research emerged out of the need to reflect on gender-related issues, especially regarding Queer Theory, gender inversion and gender polarisation, in The Ring of the Dove by Ibn Hazm of Cordoba. The objective of this study is to give broader perspectives in teaching Arabic, with emphasis on the importance of the cultural awareness regarding issues related to sex and gender. The methodology applied in the research consists of selective literary analysis, comparison, juxtaposition and contrasting of previous findings on the matter as opposed to the actual text in different versions. As a result of our investigation we can reaffirm some already established findings and also contribute new ones concerning sexual autonomy presented in the treatise. In conclusion, to some extent The Ring of the Dove is liberated from its medieval dogmatic shackles with respect to sexuality and gender affiliation.
\end{abstract}

Keywords: sexuality, gender

\section{Introduction}

With all its complexity, Arabic represents one of the most difficult languages to teach. Oftentimes students come across numerous difficulties such as memorising and correctly using certain graphemes and sounds. As an addition to the linguistic aspects, probably one of the most convoluted is adoption, and comprehension of cultural countenance related to present and past civilisations using Arabic as a mother tongue. This being the case, our objective is to elaborate the cultural aspect, as basis in learning Arabic language in relation to Andalusian literature reflected in The Ring of the Dove by Ibn Hazm of Cordoba. Guijarro Ojeda and Ruiz Cecilia (2013) assert that the essence of a given language is embedded in the comprehension of its cultural components. Hence, Arabic as a language assists in channelling crucial cultural elements. Furthermore, Guijarro Ojeda and Ruiz Cecilia (2011) indicate that different ideas are enclosed in a given language which directly correlates its essence to the 
culture in question. Emmitt and Pollock (1997) also address culture as an important agent in the formation of a language, hence the former is reflected in the latter. The intertwining of culture and language is also recorded by Allwright and Bailey (1991). Thus, learning Arabic does not solely represent memorising grammatical rules, phonetics and application of learned vocabulary, but it also carries the cultural load encapsulated in the language (Allwright and Bailey, 1991). Therefore, learning a foreign language entails learning its culture. Consequently, Arabic teachers are to indicate that the cultural connotation and the historical background of Arabs plays a huge role in sifting linguistic matrixes grounded in the diachronic evolution of the language. Accordingly, Byram (1989) points out that language teachers are also ambassadors of culture. Moreover, Elaldi (2016) suggests that literature must be used in language classes as it serves as an engine which creates consciousness in students, and promotes understanding diverse variations in formation of the cultural awareness process. Therefore, combining culture and literature in the teaching process helps in discovering cultural patterns expressed in the language (Elaldi, 2016). Through literature, students can better understand the cultural differences between Arab culture and the culture of their own. Hence, for a native speaker, it does not represent a difficulty to correctly express him/herself, as the cultural codex is fixed in the language he/she uses. On this, Xu (1997) argues that at birth, all children are the same, but since childhood those start to distinguish cultural matrixes which leads to proper use of the language. Brooks (1986) postulates the theory that all people think and act similarly as far as their biological and cognitive setup is concerned. Furthermore, he asserts that the interactions in the society, between individuals, or even entire groups mark the distinctive features in their cultural correlations. As such, the latter produce distinctive patterns that emanate from conducts which may be accepted or reprobated. Hence, a person being native in Arabic would behave differently to certain external circumstances to an individual having another language as his/her mother tongue. Therefore, the external cultural factors need to be transferred to students learning Arabic. This would result in successfully comprehend the expressions used in certain cultural context as language sets the basis of the culture (Brooks, 1986). Moreover, the language is a vessel carrying and transmitting ideas which most of the times are specifically related to the cultural background (Hantrais, 1989). However, Emmitt and Pollock (1997) indicate that cultural background as similar as it might be, people who speak different languages are found to behave similarly, and those who speak the same language forge resembling behavioural patterns. Those can be identified not only in spoken language, but also in the written one. When talking about Medieval Andalusian literature, we have to bear in mind that certain stereotypes were differently understood in Al-Andalus to how they are perceived today, especially elements related to sexuality and gender. Therefore, with this paper, we intend to give a new perspective to the interpretation of The Ring of the Dove as an important didactic material in learning Arabic language, literature and culture. Not only will we examine the treatise from Gender and Queer Theory perspective, but we will also introduce Gender Polarisation as an important factor in the physiological analysis of the notions expressed in the lines of Hazm's work. This is a key factor in our discussion, as bodies by their nature and biology can be male or female, but Hazm does not use any identifier, when talking about amorous or sexual relationships, that would indicate that bodies are different and belong to the opposite sex.

\section{Objectives}

The objective of this study is to present the cultural importance of Medieval Andalusian literature in studying Arabic language. We intend to give broader perspectives to teachers dealing with students whose native language is another. By dissecting The Ring of the Dove by Ibn Hazm of Cordoba through Queer Theory we offer specialised didactic material which would contribute not only to enhancing vocabulary and 
grammatical structure, but above all it will rise cultural awareness and understanding of crucial topics such as sex and gender. At the same time, it will enrich and bequest further comprehension of Islamic points of view regarding the above mentioned issues.

\section{Method}

\section{Instruments}

In this study, we combined the process of learning Arabic language and culture through the literature created in Al-Andalus, as well as analysis of the social system on the time. Our goal was to diachronically explore the importance of teaching Arabic language by dissecting its cultural values in relation to sexuality and gender. During our research we used a comparative method as an instrument in bringing to light hidden discourses in our primary text - The Ring of the Dove by Ibn Hazm of Cordoba. This investigation had a qualitative character, and it aimed to directly observe particular segments in our primary text. Those segments were elaborated with the aim of helping us in the comparison and contrast of the data. Therefore, the process of analysis does not carry a linear character, and there is no strictly defined sequence of the process itself. The markers that we were looking for in the chapters of the treatise enabled us to extract data which gave us information on individuals or entire groups. The latter agents made it possible to contextualise the events which indicated certain behavioural patterns propagating specific cultural matrices. On the other hand, behavioural patterns related to imagery, perceptions, interactions, beliefs, thoughts, emotions and descriptive experiences evinced certain idiomatic usage of the language. All these characteristics resulted in manifesting individual or collective behaviour uncovering the cultural awareness of Medieval Al-Andalus.

\section{Procedure}

The evaluated samples entail: ordinal variables such as involvement of given subject, social strata, social activities involvement or intellectual level; and nominal variables which include gender, sex, ethnic background or religious inclination. In our analysis, we also incorporated certain events which reflect the social life alluding to stereotypes and ideologies of the time. Hence, we revised the rules and the norms which revealed the meanings of social interaction within individuals and groups. Additionally, we reviewed the practices incorporated in the social system. Those most of the times resulted in routine actions done mechanically, but still, they were recorded in the literary cannon reflected into descriptions of rites and rituals. All this would not be possible if we had not compared Ibn Hazm's treatise on love with western ideology. Thus, we consulted authors whose thoughts prompted the decoding of given elements in relation to language teaching. Hence, those western authors stress the importance of culture in teaching Arabic. Moreover, certain elements of the secular life are encoded in the religion, thus we also analysed various aspects concerning the cultural inheritance of Al-Andalus.

\section{Data analysis}

Searching for parameters that denote social interaction between men and women was taken into consideration. Herein we analysed their particularities such as the way of thinking and the (non)expressed affections. Consequently, we had to determine stereotypes related to gender which not only were reflected in the society, but also in the literature. Hence, they created certain (in)tolerance in the ambiance. Those stereotypes represent crucial elements as far as language learning process is 
concerned. Addressing those issues prompts the cultural awareness not only in learning, but also in teaching Arabic as a foreign language. On this, Pennycook (2013) would assert that social practices are cultural manifestation of the thinking process, and as such they are directly related to the language. By analogy, the language is related to the civilisation and that encompasses the political concept of the society as well (Pennycook, 2013). Hence, analysing social patterns and practices aims in understanding Arab culture in Al-Andalus. Therefore, we first analysed biographical data about Ibn Hazm which helped us in posterior analysis of issues related to sexes, gender and queer theory, gender inversion, feminine voice, gender polarisation, and sexual autonomy in The Ring of the Dove. All this, in aim to improve the process of teaching Arabic and the cultural heritage of Al-Andalus.

\section{Results}

Teaching Arabic through the Cultural Background of Al-Andalus Reflected in The Ring of the Dove: Sexuality and Gender

When teaching a new language, especially Arabic, it is of a great importance to make students know that culture is a part of the same. One cannot exist without the other. Arabic culture is directly transferred in the active language, not only in societies of pure Arab blood, but also colonised and Islamised ones, such as Al-Andalus which was invaded in 711 (Reina, 2007). Thus, apart from using modern didactic methods, Arabic can be taught through literature. The cultural background of Al-Andalus can hugely contribute in the learning process as a lot of civilisations have left a trail on this land, and all those were incorporated and merged with the culture that Arabs brought with them (Grozdanoski, 2014). Additionally, the Arab civilisation is one of the oldest (Lewis, 1993), it carries a huge cultural background from which students can benefit. Thus, the cultural aspects are necessary if students are to comprehend the proper use of the language. Hence, learning Arabic does not only incorporate memorising linguistic rules, but it also incorporates events and other elements such as historical facts in addition to past and present everyday social, cultural and religious practices of Arabs. Therefore, if students attach erroneous meaning to some issue specifically related to Arab or Muslim traditions can be detrimental if used in a wrong context. Thus, it is essential for teachers to use appropriate styles while teaching, as that can reduce the differences in understanding certain matrices between the target language and the students' mother tongue. For these reasons, understanding the cultural background of native Arabic teachers is crucial, as they may have different ideas and ideology as far as methodology is concerned. On this, Pennycook (1994) would say that Middle Eastern educational system postulates the teacher at a higher level and his/her role in the classroom is supreme, while in present western civilisation the education is typically student-cantered. Moreover, Murray (1982) adds that very formal teaching style, and restricted interaction to the teacher would be unsuccessful in the western world. Thus, Arabic language class (if delivered in a western country) must be conveyed in significantly relaxed ambience as it would result in less tensed students. Hence, to engage students in free conversation, teachers can offer literary texts which would trickle students' reaction in distinguishing cultural and traditional values of Arabs. Therefore, teaching culture in diachronic fashion is another way to convey the cultural differences, as it can be incorporated in addition to everyday modern topics which leads to improving mutual interaction between students and teachers. Thus, teaching Arabic language also means teaching Arab culture, it is important to understand where the students come from (Engelbet, 2004). Comparing students' cultural background to the Andalusian cultural set-up is essential in understanding Medieval literature, and the language was the same. Moreover, students would also compare vocabulary and style differences in language. However, the sentence structure of classical Arabic (with its dialects) used in Medieval Al-Andalus is practically the same as in modern Arabic 
(Sattar, 2002). Furthermore, besides the time gap differences, in The Ring of the Dove there are instances that show differences related to sexuality in Al-Andalus and some present Islamic societies. On this Grozdanoski (2014) would assert that sexual relationships in the Andalusian society were widely accepted, especially the ones involving same-sex partners. Hence, methodology used in class must respect everyone's cultural background in relation to sexuality. From here, culturally acceptable patterns are as important as the ones which are unacceptable. The physiological factor of how students perceive those differences is one of the elements teachers have to have in mind, as Spence (1985) points out that in Middle Eastern culture sociological patterns dictate the behavioural matrices of the population. Those matrices are embedded in the language itself, and that dictates the permissiveness of the collective to which the individual belongs to (Spence, 1985). Therefore, cultural limitations affect interaction (Porter, 1987), as the freedom of expression, especially sexual, is bounded to the culture itself. Hence, students must be instructed that accepting cultural differences (whatever background they may have, religious or otherwise) would result in better comprehension of the language learned, and would substantially help in correct usage of Arabic phraseology and vocabulary. In addition, Hui (2005) would say that freedom of speech is one of the most effective methods in learning grammar and vocabulary, which indicates that if there is a restrictive use of phraseology in the classroom or in modern texts of Islamic origin, students would fail to recognise those cultural patterns which in the The Ring of the Dove are freely expressed. Thus, teaching by the aim of literary texts would prompt vocabulary enrichment. Furthermore, gender related issues in Arabic culture are controversial, and a proper grammatical style should be used in order to correctly express the interaction between individuals and their position in the society (Prodromou,1988). Hence, the phraseology used dictates peoples' place in the groups, and that is directly correlated to the cultural predispositions in a given society (Prodromou,1988). Maley (1986) argues that distinctive societies interpret literary texts differently. Thus, reading material should be carefully selected as students do not always tend to elucidate correctly the meaning in the samples, thus erroneously chosen didactic material can prompt controversy by attaching incorrect meaning (Maley, 1986). Therefore, teachers must be aware that students do come from different cultures, and what it might seem to them as repulsive or acceptable for that matter, it can be quite opposite present and past cultures of Arab origin. Hence, when teaching Arabic through literature, it is essential to familiarise students with the author's cultural background as that would help in better understanding his/her writing. In the following dissection of The Ring of the Dove we offer not only biographical information about Ibn Hazm of Cordoba, but we also analyse his capital work form Queer Theory perspective. The author's usage of feminine voice and gender inversion would improve students' understanding of cultural differences in Medieval Al-Andalus. Additionally, the elaboration of gender polarisation and the sexual autonomy in the treatise enables students to correctly understand love and affection as part of every culture, especially in Medieval Islamic society.

\section{Ibn Hazm's Life and Work}

According to Reina (2007), Ibn Hazm (Abu Muḥammad 'Ali ibn Aḥmad ibn Sa'īd ibn Hazm) was born in 994 in Cordoba and probably died in Badajoz or Huelva in 1064. However, Encyclopaedia Britannica gives November $7^{\text {th }} 994$, Cordoba ${ }^{1}$, and August $15^{\text {th }}$ 1064, Manta Lisham, near Seville, as the date and place of birth and death. Ibn Hazm was not only a prolific litterateur, but he was also a historian, a jurist, a theologian and one of the leading figures of the Zāhirī school of jurisprudence. He is believed to have produced approximately 400 works encompassing ethics, logic, history, religion and theology. Hazm wrote some 80,000 pages, including Fisal, or

\footnotetext{
${ }^{1}$ Then the Caliphate of Cordoba.
} 
Critical History of Religious Ideas, an advanced comparative theological treatise considered to be the first ecumenical history dedicated to Christianity and Judaism (Reina, 2007).

Ibn Hazm collaborated in Caliph Abd al-Rahman Mustazhir's government issues on coexistence and cultural splendour. However, not long after the caliph's execution, Hazm was imprisoned. Nonetheless, Hazm excelled as a result of his continuous nonconformity and revolutionary audacity. Although the Maliki school of thought reigned supreme in Cordoba, Ibn Hazm decided to follow the ideology of Zahiri master Abu-I-Jiyar. From 1027 to 1029 he taught at the Great Mosque of Cordoba, but at no time did the Maliki inform against his revolutionary ideas, which posed a threat to the religious orthodoxy, corrupting believers, shaking up the conservatism and spreading permissiveness towards other religions. Soon enough, his teachings at the Mosque were forbidden, mainly because he was manifesting such a great interest in Christianity. He wrote a text on the Gospel of St. Luke. He also made "a comparative study on the religious pluralism of his day, which is among the earliest of such studies and is highly regarded for its careful historical detail" (Encyclopaedia Britannica). Consequently, his books were publicly burned in Seville. "On this he responded that no such act could deprive him of their content" (Encyclopaedia Britannica). As most of his canon was destroyed, only few treatises, such as The History of Religious Ideas, On the Love of Lovers and The Ring of the Dove, survived (Reina, 2007).

Ibn Hazm was a fierce polemicist, attacking his opponents eloquently and fervidly. He knew how to address his critiques against anybody who did not share his heterodoxy. His tongue was compared to Al-Hjjaj's ${ }^{2}$ sword. While polemicizing, Hazm spoke clearly. He had no restraints, reluctance or subtlety when expressing his thoughts. Hazm was a man who always ignored the art of politics. When somebody tried to trick him, he would act reserved, just as he would suddenly erupt in response to the smallest remark or a meaningless question. Later, Hazm decided to retire from active political life and devoted himself to theological and legal studies. As a result of his activities and political and intellectual points of view, he died in exile, despised by the new ultraconservative leaders (Reina, 2007).

\section{Sexes, Gender and Queer Theory}

When we desire something, we must find a means of reaching it or a way that leads us to it, for the only one that can create as he pleases without intermediaries is the Prime Omniscient Himself (be He ever praised and exalted!) (Hazm, 2015, p.172).

These are the opening lines of the chapter entitled On Verbal Allusions. It is impossible here to determine where or whether the author refers to one gender only. He starts with an explanation of what desire is, and he concludes that this is locked within the deepest place of the Almighty (God). God has no gender identity, he is everything and he is all. There is no limitation to his powers, and having that immense knowledge he does not need to be placed within the frames of gender identity. Implying theological thoughts in the work, Hazm breaks the established code and sometimes he refers to the individual without giving it male or female characteristics. This is the first step to gender (non)identity.

What can be meant by "identity", then, and what grounds the presumption that identities are self-identical, persisting through time as the same, unified and internally coherent? More importantly, how these assumptions inform the discourses on "gender identity"? It would be wrong to think that the discussion to "identify" ought to proceed prior to a discussion of gender identity for the

\footnotetext{
$27^{\text {th }}$ century general and governor of Iraq (Encyclopaedia Britannica).
} 
simple reason that "persons" only become intelligible through becoming gendered in conformity with the recognisable standards of gender intelligibility (Butler, 1999, p.22).

Accordingly, how can we be sure what a gender identity is? Gender identity is to be understood independently of sex, and applying this tool we can identify that in The Ring of the Dove there is a certain gender displacement and exchanging of gender roles. In some of his lines there is no equivalence between gender and sex; it all seems to be floating in the air, referring to bare feelings and emotions without focusing on the individual's biological sex or inner gender. In any case, many times throughout the treatise there is a deliberate absence of biological sex identification. Thus, the writing is ambiguous in respect of gender. Language wise, there are some discrepancies that do not allow us to determine the actual sex of the person in question. When in the following verse Hazm uses the word "beings", is he referring to a man or to a woman? - Probably to both, which indicates that there is no gender involved in his intention of depicting the affection:

The first task that those who long for union and lovers tend to undertake, to declare their feelings to the beings they love, is that of verbal allusions. These can be made reciting allusive poetry, naming a suitable proverb or an enigmatic verse, quoting ambiguous phrases, or intentionally emphasising words (Hazm, 2015, p.22).

Let us look at another poem from The Ring of the Dove in which the lines are freed of gender and sex. In the tone he uses to describe one of the lovers in the relationship, where supposedly both are from the opposite sex, there is something that makes his description not correspond to opposite-sex individuals. In order to avoid revealing the lovers' identity, Hazm depicts them very cautiously by using the first person singular in his discourse. That is how the second lover's sexual identity stays hidden.

A youth as handsome as a gazelle,

As fair as the full moon or

The sun shining between the clouds,

Captured my heart with his languid glances

And his waist branchlike in its slenderness (Hazm, 2015, p.174).

In respect of the linguistic and sociological discourses that occur in Hazm's writings, we can connect them to Butler's concept and what she wrote on the issue: "Sociological discussions have conventionally sought to understand the notion of the person in terms of an agency that claims ontological priority to the various roles and functions through which it assumes social visibility and meaning (Butler, 1999, p.22)".

On the question: "What is a personal identity?", Butler argues that philosophy almost always tries to give a response to the question related to the internal feature that the person establishes, whereas the self-identity of the person unfolds through time (Butler, 1999). Furthermore, she adds that the regulatory practices that "govern gender also govern culturally intelligible notions of identity (Butler, 1999, p.23)". As a consequence, the coherence and the continuity of the individual seem to be illogical and lack analytic features of "personhood", and as a result they are "socially instituted and maintained norms of intelligibility" (Butler, 1999, p.23). However, in society the "identity is assured through stabilising concepts of sex, gender, and sexuality, the very notion of the person is called into question by the cultural emergence of those incoherent or discontinuous gendered beings" (Butler, 1999, p.23). This issue can be perfectly observed in The Ring of the Dove where we can see how those beings Butler is talking about "appear to be individuals who fail to conform to the gendered norms of cultural intelligibility by which persons are defined" (Butler, 1999, p.23). 
My love for you is immutable,

while so many human loves are but illusions (Hazm, 2015, p.25).

Butler's definitions of attributing any of the known genders fails to fit so far into Hazm's way of interpreting human notions. However, we can to some extent say that Butler's perception occurs in his work as she says that gender and sex differentiations do emerge from socially established norms. Whatever the case, we have to take into consideration the fact that the social norms reflected in The Ring of the Dove are an Islamic Medieval construct, and as such, they may or may not coincide with the norms Butler is talking about, established in the $20^{\text {th }}$ century.

If we try to identify the gender predisposition of the writer's voice, we will certainly become confused, as the norms applied here addressed the notions of love the author held. "I profess a pure and untainted love to you" (Hazm, 2015, p.25). This is another case where we cannot know to what sex he is referring, or whether he is deliberately hiding the gender due to the norms that then existed in society. However, Emilio García Gómez gives us information that the following lines are actually dedicated to a man. $\mathrm{He}$ also informs us that love was not understood equally in those days as it is today (García Gómez, 1965):

Your affection is visibly engraved on my heart.

If in my soul there were any other thing but you,

I would rip it out with my bare hands.

I don't want anything from you but love;

I ask you for nothing else.

If I attain it, the entire Earth and all mankind

would be naught but dust motes and its peoples, insects (Hazm, 2015, p.119).

We can observe that Hazm is concealing the real identity of the person whom this poem is dedicated to, which results in querying of the same, and by that querying his own gender. In his preface to The Ring of the Dove, José Ortega y Gasset gives us supporting information on this issue. He asserts that love in Europe is generally understood as sharing feelings between two individuals from opposite biological sexes, that is to say a man loves a woman, and in response that certain woman returns love to the same man (Hazm, 2015). He adds that in order to understand that love can be given from men to men and from women to women, what we need to do is to disarticulate the primary meaning of the word "love" and rearticulate it in a way that will open possibilities in figuring out the homosexual eroticism (Hazm, 2015). Doing this, it will most certainly give us a preview as to what queer means, and how love is not restricted to either of the biological sexes.

\section{Gender Inversion and Feminine Voice}

Gender inversion and usage of the female voice in male poets in Arabic literature was a very common practice. The Ring of the Dove is not an exception and throughout the treatise we come across many passages where Ibn Hazm adopts a female voice while expressing his sentiments. Having its basis in the Islamic traditions, regardless of whether they are religious or secular, this voice adaptation is often used in addressing the beloved. Although it is quite frequent for a man to adopt a female voice, there are also cases where a female adopts a male voice (the latter is not very common in The Ring of the Dove). As Al-Andalus was Islamic territory, the singers and the poets of the time meticulously followed the Islamic matrixes, thus Hazm is embracing not only the culture, but also the linguistic traditions as well as the tendencies of the time (Grozdanoski, 2014). 
I keep distant from the one I love, and not because of hate.

Marvel at a lover who stays away!

But my eyes cannot rest upon the face of the treacherous gazelle (Hazm, 2015, p.225).

These lines are a fine example of how gender exchange happens in Hazm's writings. The poems start in a very neutral tone and there is no distinction of gender. He is opting for a neutral gender and appears to adopt feminine characteristics while reciting this poem. There seems to be a confusion presented to the reader, as the latter cannot determine whether the writer is man or a woman. The same goes for the addressee in the poem: "[...] the one I love," writes Hazm. But who is he referring to? Who is the lover? - There is no gender affiliation. Anyhow, the gender of the poet can be suspected in the second line: "Marvel at a lover...". This might indicate that the verse was written by a woman, as generally women have the tendency to express their feelings more elegantly and softly. Thus, we can conclude that after all the gender of the poet might be female, as far as this particular line is concerned. If we analyse the third line, we can see how he slightly introduces the gender. He is calling the lover "gazelle", and this term was used exclusively to identify a young man.

Butler is talking about previously established gender norms, which function as a type of a matrix where people try to fit in all human beings (Butler, 1999). In Hazm's The Ring of the Dove, this matrix is ruptured, as he relates issues directly connected to the human soul, not a precise gender to which the author or the addressee could belong. However, he starts with one rather religious description where obviously the male soul belongs to a female one, and he meticulously talks about the creation of men and women, but towards the end of the passage he escapes from that singularity and he enters into rather uncharted waters. Hazm explains that each soul looks for its counterpart according to its "nature" (Hazm, 2015). "Nature" here is the crucial word, as he is not pointing out either of the sexes.

Certain disciples of philosophy have claimed that God - praised be His glory! created all spirits in rounded form like spheres, and then split them in two halves, placing each in a body. This is why each body that finds the other that holds the other half of its spirit, loves it, due to this primal affinity, and thus humans come together according to the needs of their natures (Hazm, 2015, p.84).

What is very curious here, whatever religious context these lines may carry, is that Hazm omits to point out that the two parts of the soul are placed in different sex bodies. Accordingly, we can only theorise that the two parts of the soul have different gender. We can see how he refers to a "body" where the souls are placed. Thus, each body has its necessity, but what is the necessity? - Looking for an opposite sex body? Even so, it is not mentioned in the text. We cannot come to this conclusion simply because we assume that a body from one sex looks for a body belonging to the opposite one. Gender neutrality is observed towards the end where Hazm explains that "necessity" is what drives the body in search of the missing part of the soul, according to its personal necessities (Hazm, 2015). That missing part might equally be placed in a male or a female body. Thus, neither the first nor the second body is gendered. In response to this we can say that a female soul seeking the other half of its soul may search for a female or a male body, as may a male also seek a female or a male.

\section{Gender Polarisation}

Ryle argues that the polarisation of genders is a concept that has a tendency to define and explain masculinity and femininity (Ryle, 2012). This concept represents the genders as polar opposites. It includes certain traits and behaviours resulting in 
attitudes that are perceived as male-acceptable and appropriate for men, while, on the other hand, there are attitudes and behaviours that are defined as female-acceptable. In addition, there is a division of masculine and feminine traits that are reflected in The Ring of the Dove. The masculine traits are: rational, aggressive, dominant, reasonable and individualistic; and feminine traits are: emotional, passive, submissive, sensitive and nurturing (Ryle, 2012).

These socially constructed activities, behaviours, attributes and roles are considered to be appropriate either for men or and women. Further on we will see how these rules are broken in The Ring of the Dove, and how sometimes there is an overlapping of the roles a man and a woman should have. In any case, not all of these traits appear in the treatise, for, I repeat, this is a medieval work and the perception of the world then was quite different from today's conception of male or female traits. This being said, we will analyse the following traits: rational, emotional, aggressive, passive, dominant and submissive, which are essential for this research.

\section{Rational versus emotional}

If being rational is a male trait, and being emotional is a female trait, they should be confined to male and female bodies, respectively. Nonetheless, this concept and division of masculine and feminine traits is not applied in The Ring of the Dove. The simple reason for this is that, in all his wordplay, Hazm is mixing and reversing the traits, and sometimes we have an allusion that the lines are written by a female author, as they are abundant in emotions.

Was she an idea that the mind conceived in its reflections?

Was she a spiritual vision conjured by my thoughts?

Was she a phantom forged from the hopes of the soul

And that my sight imagined it had found (Hazm, 2015, p.79)?

As it can be seen, the author is blinded with the image of a ghostly figure that appears in front of him. This figure represents an emotional reflection of his affinities and he is dazzled with the idea of his vision. He is stating that this figure is "a phantom forged from the hopes of the soul", which indicates that the emotions are overcoming his reasonable thinking (Hazm, 2015, p.79). According to the polarity of gender, and the male being completely opposite to the female, a man should not express such a behaviour where he would pour out his emotions and go deeply into his soul, as women are considered to be more emotional and by that more spiritual, where the soul is directly connected to their feelings and casts out the rational perception of the world. Moreover, ghosts have no gender nor sex, thus we cannot define it as a male or a female apparition.

Oh my hope! I delight in the torment I suffer because of you.

As long as I live, I shall never let you go.

If any were to say to me: "You'll forget his love one day,"

I shall merely reply with an $\mathrm{N}$ and an $\mathrm{O}$ (Hazm, 2015, p.137).

In the first verse of the poem he is stating that he is tormented and he is suffering. A man, according to his rational nature, should not be tormented, much less suffer for love. Even more, he should not express his suffering as that is not a male trait. In the second line he is augmenting the expression of his feelings as he states that he would not part from his beloved until his last breath. Furthermore, his love is being expressed even more evidently and he uses the word "love", which indicates that his feelings are quite strong.

Yet, here we come to another example where feelings are clearly expressed. Hazm writes: 
Melancholic, distraught and sleepless,

the lover is endlessly complaining, drunk on the wine of calumny (Hazm, 2015, p.145).

Melancholy is one of the strongest feelings one might have. Thus, this precise word is used in the beginning of the line to stress how deep his sentiment was. Furthermore, he states that he is "distraught and sleepless", taking the role of a lover. However, in these lines it is not clear what the gender of the lover is. The gender identity is hidden, thus in the second line, in the translation, remaining merely "the lover". So, is he using a female voice here to depict his state of soul or is he just depolarising the gender? - In my opinion, he is precisely doing the latter, he is depolarising the role of gender. Likewise, in the following lines, in which he describes a person who might be a friend and an enemy at the same time, which indicates that he might be talking about a male lover, because it was more common to have friends from the same sex, rather than the opposite.

In an instant it makes you see wonders, one moment foe, the next a friend, Coming close and running away alike (Hazm, 2015, p.145).

The poem ends with a strophe where Hazm is expressing an idyllic image of a garden full of white flowers that appear to be frosted.

We delighted in the white flowers of the garden, grateful and enchanted for the frosty watering: dew drops, cloud and sweet-scented orchard seemed our tears, our eyelids and his rosy cheek (Hazm, 2015, p.145).

The frosting refers to their frozen feelings, which blossom all over again after the reencounter takes place. The final verse reveals their feelings as happiness upon that reencounter and it results in tears being shed by both lovers. In this case there is no polarisation of the lovers' gender. If supposedly they were from opposite sexes, they should not act the same, since crying, at that time, was a stereotype of a female emotional expression, not typical for men.

Furthermore, in the Spanish version of the text, "grateful" and "delighted" are used in their feminine form "agradecidas" and "encantadas", which indicates that here we might have two women lovers, and in that case we do not have polarisation of the genders, as explicitly expressing sentiments is exclusively a female trait. However, we cannot be sure that he is talking about two female lovers, because in the previous line "....and I came to be envied, having earlier been envious" (Hazm, 2015, p.145), which is connected to the lines quoted above, Hazm uses the masculine gender for the adjectives ("envidiado" and "envidioso").

\section{Aggressive versus passive}

In psychiatry, passive-aggressive behaviour refers to the passive and obstructive resistance to institutions and authorities in daily situations of personal and professional aspect. It can manifest itself as resentment, sloppiness, stubbornness or intentional failure to perform the required tasks. The simple fact of being passive-aggressive is not a disorder but a behaviour. The common signs of passive-aggressive personality disorder which serve in determining if one behaviour is passive or aggressive or both are: ambiguity, chronic daily forgetfulness and frequent lapses in memory, blaming the other, fear of authority, fear of completion, fear of intimacy, fomenting chaos, intentional inefficiency, making excuses and telling lies, obstructionism, leaving things to be done 
later, resentment, resisting suggestions from others, sarcasm, etc. (American Psychiatric Association, 2013, pp.733-734).

In The Ring of the Dove some of these behavioural patterns can be observed, either completely or partially. On some occasions the behaviour is quite passive, thus the stereotype of males having aggressive behaviour is countered. Seemingly, we have gender depolarisation where a male individual, in this case the author himself, has a form of conduct that is not on the extreme pole of male-type behaviour. Passiveness can be observed in the lines where he subtly bows to what may be an authority, and that is the beloved or love itself as a sentiment, which is reflected in the following lines.

Until nightfall I was waiting to see you,

Oh my desire! oh peak of my yearning!

But the darkness made me lose hope,

When before, even though night fell,

I would not give up hope that the day would go on (Hazm, 2015, p.146).

Another sign of passive behaviour is general forgetfulness, which in the end results in forgetting the beloved one and separating one's thoughts from the subject of adoration. In the $27^{\text {th }}$ chapter, Hazm gives a general description of forgetfulness, which is rather rational as he does not place himself in the position of a person who is acting that way, but he just depicts what happens when an individual act in quite a passive way: to forget about things that are surrounding him/her, including the beloved, who is no longer present in the lover's surroundings (Hazm, 2015, pp.313-331).

And on the question - What, really, is forgetfulness? - he gives the following answer:

Regarding the oblivion that is born of prolonged disdain, it is naught but the despair that assails the soul when it cannot attain what it yearns for; which makes the struggle cease and the desire weaken (Hazm, 2015, pp.314).

In any case, Hazm's lines show meaningless signs of aggressiveness, generally aimed at the beloved. The lover can act aggressively for several reasons, one of which might be the fear of losing his beloved. Another can be resentment or ambiguity. In the following lines, there is a mixture of ambiguity and fear, and the aggressive behaviour can be observed in the first line of the poem:

Leave me to insult the one I love,

for though I seem scornful, I am not hostile.

My insults against my beloved are

like when they say: "Kill him God and good riddance!" (Hazm, 2015, p.315).

As Arabic poetry is the most sublime written expression in Arabic literary tradition, we can hardly ever come across elements of a destructive nature in The Ring of the Dove. That being said, we can add that The Ring of the Dove has a more passive connotation rather than an aggressive one.

\section{Dominant versus submissive}

We find that the soul is dominated by certain forces that act upon it within the body. There are souls that abandon delights and pleasures to shelter in obedience to God Almighty, or to gain fame in the world once their austerity becomes renowned (Hazm, 2015, p.313).

The $14^{\text {th }}$ chapter is devoted to submissiveness. Hazm starts the chapter by explaining what submissiveness is, and how it is reflected in amorous relationships. He is 
generally in defence of submissiveness. He explains that this trait is one of the most beautiful things, and if the lover submits to his beloved he will really feel the essence of love. According to Hazm, submissiveness transforms people and makes them bring their inner gentleness and softness to the surface, which sometimes may be covered by a mask we all wear, and our superficial and outer image may give a false impression (Hazm, 2015, p.313).

Will the times of being together return for us?

Will there be a limit to the tos and fros of this Fate? (Hazm, 2015, p.195)?

In the first verse, the author is wondering whether he will be reunited with his beloved. By questioning himself, he is positioning himself as an object in the poem and he is taking the role of the submissive one in the relationship. There is no preface to these lines, thus we cannot know why he is saying all this. However, we can assume that his beloved is gone, and his departure was not the poet's wish. That is to say, the beloved had a dominant position and decided to leave his lover. In the second verse, Hazm is praying for destiny to take its turn and bring his beloved back as he is suffering from being separated from his lover. His sorrow can be observed in the following two lines where the author is trying to give us a description of how once his beloved was submissive and now he has turned himself into a "lion". He is now the dominant one and he does whatever he wants, not taking the feelings of the lover into consideration.

The sword has become slave to the stick.

The captive gazelle has become the lion. (Hazm, 2015, p.195).

Furthermore, the submissiveness of the author is reflected in the lines that follow:

When you reproach me, I am the basest of those condemned to death, the false coin spurned by the moneychanger.

But, moreover, I find pleasure in dying for your love,

What wonder a man condemned to death who is overjoyed! (Hazm, 2015, p.195).

With these verses Hazm presents a situation that creates tension towards life itself. He points out that death is welcome: when his lover reproaches him, it makes him weak. That weakness reflects notions of submissiveness as his strength is almost gone when he is close to his lover. This humbleness and prostration in front of the lover is precisely the kind of imagery that depicts submissiveness. Furthermore, this submission is reflected in the second line where he adds that he is like a false coin, the coin being the smallest unit in the exchange of goods. Finally, he finishes the poem with two verses where for him death is the only joy should he be left alone without the company of his beloved.

In addition, Hazm gives us information that the one who is in love does absolutely everything for his beloved. There is no limit to what a man in love could do. However, as difficult as the situation might be, the lover always finds a way to justify his beloved's actions. For the one in love the insults don't matter. He might be accused of many things, but in the end he accepts everything and continues being loyal and subject to his lover's will (Hazm, 2015, pp.195-202).

Further on, Ibn Hazm relates the story of a young boy who was severely punished, and yet after receiving his punishment he continued being submissive to his master. Moreover, he liked the punishment and looked upon it as something to be expected. This expectation provoked happiness in the boy (Hazm, 2015, pp.195-202).

Hazm continues to give us examples of lovers who were being submissive. Here I present one more example of a lover who is submissive to his beloved. In this case we have a termination of a relationship. The lover decides to end the affair, just to comply with his beloved and grant his wishes, although the termination of the relationship 
would have serious repercussions on the lover's state of mind and soul (Hazm, 2015, pp.200-201).

Hazm finishes this chapter with a story of another person he knew, a friend of his. He tells a story where the lover decides to do nothing, very similar to the previous example, as he thinks that the feelings and the soul of his beloved are more important than his own. That way (although he has very strong feelings toward his beloved) he does completely the opposite of what his heart is telling him to do (Hazm, 2015, pp.201-202). Refusing your own wishes and putting someone else's needs before yours is a perfect example of submissiveness.

\section{Sexual Autonomy}

Butler questions the very essence of life and what it means to be in a world that has perpetual issues of what makes it liveable. She addresses her questions to the ethics and the personality each one of us possesses. On the question of what makes life bearable, - she simply explains that all we have to do is to perceive the world from our own perspective and question ourselves: what makes us human? From what perspective should we observe life and what constitutes the human (Butler, 2004)?

These are precisely some of the questions Ibn Hazm was asking himself hundreds of years ago, at a time when human rights and the human perception of the world were so different from the present (Hazm, 2015). In this respect, love is free and liberated of shackles, and consequently sexuality receives the same treatment. Free and liberating. As love is an autonomous feeling that can be neither forced nor retained, it may appear in many different forms and towards individuals of the opposite or the same sex. Here we come to the same concept Butler is postulating in Undergoing Gender (Butler, 2014). Thus, we have to understand that the essence of life and living in a world that sometimes deprives us of our essential needs, wishes and desires is complex, and demoralises the individual's inner self. This is illustrated by a passage where Hazm is giving us a description of someone with whom he fell in love. Interestingly enough, in these cases we have a slave, whose gender is not given. In any case, the fact that she or he is a slave gives us a clear picture that the heart does not distinguish when it comes to falling in love: rich or poor, man or a woman.

In my youth I loved a slave who happened to be a blonde; from that time, I have never admired brunettes, not though their lark tresses set off a face as resplendent as the sun, or the very image of beauty itself. I find this taste to have become a part of my whole make-up and constitution since those early days; my soul will not suffer me to acquire any other, or to love any type but that (Hazm, n.d.).

The meaning of sexual autonomy does not simply refer to being free to do what you want, to convey chaos in society, but to being liberated from frustration and following an "expired" codex in order to be better accepted in society, or simply to fit in well without it being noticed that you as an individual are different from the rest of the flock. However, sexual liberation means something more, to be able to freely follow your desires and make a decision based on what you feel and what your aspirations are. Being able to love whomever you want, and follow your own heart, not dividing individuals between men and women, can be observed in the $7^{\text {th }}$ chapter, where Hazm explains that love exercises a powerful effect upon the soul, a decisive dominion with an irresistible authority, a force against which we cannot fight (Hazm, 2015). He stated: "It is a sovereign that cannot be escaped, that enforces unavoidable obedience and compulsion that nobody can evade," which no one is capable of destroying (Hazm, n.d.). On the contrary, it is love that "destroys the hardiest, unravels the toughest, fells the most solid, unsettles the firmest, is lodged in the deepest region of the heart" (Hazm, 2015, p.167). 
On the other hand, however progressive Hazm's thoughts might be, he is still subject to religion and the aspect of autonomy is not entirely free from God's will, and it is not completely dependent on one's personal affinity or just a simple desire. For example, Hazm asserts that people react differently when they love one or another person. It is interesting that in none of the lines he wrote on this issue, there is no tendency of gender differentiation. He states that, in his experience, he has seen a lot of people who show nothing suspicious and there is no lack of understanding nor disturbance in their judgment, not even deficiency in their mind, when it comes to depicting their beloved (Hazm, 2015).

In the following quotation, we can observe that Hazm never uses gender to point out the sex of the beloved, nor does he use descriptive adjectives that might suggest that he is referring to a male or a female individual:

All the Caliphs of the Banu Marwan (God have mercy on their souls!), and especially the sons of al-Nasir, were without variation or exception disposed by nature to prefer blondes. I have myself seen them, and known others who had seen their forebears, from the days of al-Nasir's reign down to the present day; every one of them has been fair-haired, taking after their mothers, so that this has become a hereditary trait with them; all but Sulaiman al-Zafir (God have mercy on him!), whom I remember to have had black ringlets and a black beard. (Hazm, n.d.).

We only have adjectives that describe the lover's sex, or in some cases he is using male personal or possessive pronouns and adjectives when he talks about people in general. Thus, we can note that sexual autonomy is preserved as far as the sex of the beloved is concerned. Additionally, he does not give any indication that the individual should be in love only with another individual of the opposite sex. Hazm is clearly giving more credit to the essence of love and the purity of the thought that leads to uncompromising affection directed to the persona, not to his or her biological sex and, by that, the gender. Moreover, he only gives a description of their physical beauty, not referring to gender or sex at all.

Having in mind these characteristics given by Hazm, we can say that he might be the pioneer in respect of what we today know as sexual autonomy, and it is very similar to what Butler has said on this issue. And on Butler's question "What constitutes the human?" (Butler, 2004), we can find the answer in the following lines of Hazm's where he relates that human nature is contained in the affect, and nothing else matters when it is gone.

And if later these passions faded away, whether through oblivion, absence, acrimony or through any other of love's misfortunes, yet they did not lose their appreciation of these qualities, and continued to prefer them over others that human nature possesses by way of improvement (Hazm, 2015, p.168).

Another interesting fact that we come across in the seventh chapter of The Ring of the Dove with respect to sexual autonomy is the description Hazm gives of a woman, where he points out that as a result of the tastes she has and her likings, she finds it impossible to be attracted by someone who does not fit her personal preferences. The important fact for us here is that Hazm clearly mentions the words "man" and "woman", thus sexual autonomy is reflected in the liberal election of the sexual/amorous partner.

I know, for example, of one who fell in love with a woman somewhat short of neck, and who thereafter liked neither man nor woman whose neck was slender (Hazm, 2015, p.168). 
Hazm also relates his personal preferences in describing a woman he had been attracted to, stating that no other woman managed to capture his affection as no subsequent women had the same physical appearance as she did. In between these descriptions, in a very shrouded manner, he inserts the line "nor, in effect, has [my soul] been able to love any other thing", which indicates that he is not limiting himself only to being attracted to women. In the word "thing" we can sense sexual liberty as an autonomous feeling that might refer to general attraction to a certain type of individual that is not determined as a male or a female (Hazm, 2015, p.169).

However, Adang made a huge contribution when it comes to homosexuality in relation to Ibn Hazm's personality and writing. Although she has investigated this issue in The Ring of the Dove, she argues that Hazm's perception on homosexuality is to be found in his work Kitāb al-Muhallā, where the legal point of view on liwāf ${ }^{3}$ and sihāq ${ }^{4}$ homosexuality is reflected (Adang, 2003). Furthermore, she has compared his thoughts with other Māliki jurists. As a result, she asserts that unlike other Mālikis, Hazm advocates that homosexuality is not the same as zinā ${ }^{5}$ and death should not be prescribed as punishment (Adang, 2003). Instead, he proposes 10 lashes if an individual is involved in homosexual practices (Hazm, 2013). Adang categorically refuses some modern authors' belief that Hazm himself had a homosexual inclination (Adang, 2003). Additionally, she states that Hazm condemns sexual intercourse between same-sex individuals as that act is immoral and it is a sin. Thus, she asserts, Hazm holds to the idea that homosexuals are to be reformed (Adang, 2003).

\section{Discussion}

Love has many shapes, forms and aspects. This is of huge importance, because love acts as a medium through which gender and sex issues are reflected. Nevertheless, Ibn Hazm succeeds in giving a generalised definition of what love represents. The definition is grounded in the first passage of another of his surviving works, Morals and Right Conduct in the Healing of Souls and says: "Love, in its entirety, is all of one kind. It can be described as follows: desire for the loved one, the pain and sorrow that their aversion causes us, and the desire we feel for the beloved to return our love (Hazm, 1916, p.75)".

The translation and the interpretation of The Ring of the Dove seems to have been a difficult job. The language used is quite archaic, and our modern perception of it gives us troubles understanding it correctly. If we were able to go back in time and transpose ourselves to mediaeval Al-Andalus, to understand the customs, conduct and perception of that world, we would be much more capable of understanding the essence of the author's words. Of course, this is a very complicated approach, but in any case we have to be conscious that the views on love in that time and in present days are neither so different nor so similar.

We have seen that homosexuality equals true love between men, and we find Hazm very conscious about this occurrence. As far as this work is concerned, Hazm expresses his opinion in a very confident way without feeling uncomfortable about it, nor about the sexual predisposition he relates.

We reaffirm that The Ring of the Dove is abundant in rhetoric and reflects only aesthetical values and has no other intention but to depict notions of love. As the treatise was written for mediaeval Islamic society, it is understandable that religion and morality play a huge role in its creation. For that reason, the population this book was aimed at would have certainly understood it in a different way than we do now. Thus, bypassing the time gap and abandoning all prejudices would help us understand the essence of The Ring of the Dove.

\footnotetext{
masculine

${ }^{4}$ feminine

fornication
} 
Having expressed my arguments, I can draw the following conclusions. Sexual activity was a common everyday occurrence and it was not hidden from the public perception of society. Consequently, sex and gender are intertwined throughout the work, as in those times there was no difference between these two terms, and sexual affiliation was always related to gender itself. Thus, we conclude that there is queering of gender because, when talking about love, for Hazm there was no difference between male and female individuals, as the "soul" is free to love whomever it pleases.

As a result, we come to another point and that is the gender inversion that occurs quite frequently in The Ring of the Dove. Gender inversion seen in the verses of this treatise is used as a way of expressing feelings and thoughts from the perspective of another gender, not directly ascribed to the writer, but rather to the persona he is interpreting or portraying in the verses. This gender inversion is closely related to the female voice of the author, as it happens only when a male individual (the poet or the persona) shifts their male persona into a female. Thus, we conclude that the feminisation of the writing is essential in order to reveal the inner gender expression of the author.

As a response to this, we have gender polarisation. If gender polarisation tends to explain, diversify and define masculinity and femininity, we deduce that the concepts such as rational vs emotional, aggressive vs passive and dominant vs submissive are meticulously inserted into the lines of the treatise. Hazm is constantly juxtaposing these concepts and by that he is not only applying gender polarisation to the characters, but to himself as well. Most of the time he writes in the first person singular, which indicates that his personality was polarised. Therefore, the characters described in the treatise take the above-mentioned aspects as a part of their being.

Throughout the verses of The Ring of the Dove we have seen that there are aspects that show liberty in respect of love. Hazm connects love wholly to the soul, and he does not follow the norms which dictate that one has to fall in love and form any kind of a relationship with an individual from the opposite sex. Furthermore, Hazm states that we are free to love whomever we want and it is not necessary for us to follow rules, which results in only one thing - the missing part of our soul may equally be placed in the male or the female body. From this I therefore conclude that sexual autonomy is directly related to the "broken" heteronormativity. Thus, if the missing part of our soul is placed in a body of the same sex and gender as ourselves, then there should be no obstacle for us to form an amorous or sexual relationship with that individual.

Hence, from the above we deduce that introducing didactic units closely related to socio-political issues prompt better understanding of the Arab cultural matrices. Furthermore, the latter are important when teaching Arabic language as their singularities enhance students' comprehension by helping them to attach correct meanings to phraseology and idiomatic expressions related to gender and sexuality, and how they were perceived in the Andalusian society. At the end, we conclude that cultural background is inseparable and crucial part of the language teaching process.

\section{References}

Adang, Camilla. 2003. "Ibn Hazm on Sexuality. A Case-Study of Zahiri Legal Methodology." Al-Quantara Revista De Estudios Arabes XXIV, 1: pp.5-31.

American Psychiatric Association. 2013. Diagnostic and Statistical Manual of Mental Disorders 5. Arlington: American Psychiatric Association.

Allwright, B., \& Bailey, K. M. (1991). Focus on the Language Classroom: An Introduction to Classroom Research for Language Teachers. Cambridge: Cambridge University Press. 
Brooks, N. (1986). Culture in the Classroom. In J.M. Valdes (ed.), Culture Bound: Bridging the Cultural Gap in Language Teaching (pp. 123-128). Cambridge: Cambridge University Press.

Butler, Judith. (1999). Gender Trouble. New York: Routledge.

Butler, Judith. (2004). Undergoing Gender. New York: Routledge.

Byram, M. (1989). Cultural Studies in Foreign Language Education. Clevedon: Multilingual Matters.

Elaldı, Ş. (2016). Foreign Language Anxiety of Students Studying English Language

and Literature: A Sample from Turkey. Academic Journals: Educational Research and Reviews, 11(6), pp.219-228.

Emmitt, M., \& Pollock, J. (1997). Language and Learning: An Introduction for Teaching. Melbourne: Oxford University Press.

Encyclopaedia Britannica. Ibn Hazm. Accessed November 21, 2018. https://www.britannica.com/biography/lbn-Hazm

Engelbert, M. (2004). Character or Culture? Implications of the Culturally Diverse Classroom. The Asian EFL Journal, 6(1), pp.37-41.

Gómez García, E. (1965). Las Jarchas Romances de la Serie Árabe en Su Marco (The Romance Jarches of the Series Arab in His Frame). Barcelona: Seix Barral, S.A.

Grozdanoski, B. (2014). Srednovekoven Al-Andalus, Heteronormativnosta i Seksualnosta vo Opshtestvoto Preslikani vo Knizhevnoto Tvoreshtvo vo Periodot od VIII do XIV Vek (Medieval Al.Andalus, Heteronormativity and Sexuality in the Society Transferred into the Literary Canon in the Period between VIII and XIV Centuries). Skopje: Sofija.

Guijarro Ojeda, J. R. \& Ruiz Cecilia, R. (2013): Perceptions of Spanish EFL trainee teachers on the introduction of queer Issues in the classroom. Onomázein, Revista semestral de lingüística, filología y traducción, 27, junio, 193-206.

Guijarro Ojeda, J. R. \& Ruiz Cecilia, R. (2011). Los discursos del género en Español Lengua extranjera: A propósito de Pedro Almodóvar. Hispania. A Journal Devoted to the Teaching of Spanish and Portuguese, 94(1): 13-24.

Hantrais, L. (1989). The Undergraduate's Guide to Studying Languages. London: Centre for Information on Language Teaching and Research.

Hazm, A. (2013). Al-Muhalla (The Adorned Treatise). n.d.: Turath For Solutions.

Hazm, I. 2015. El Collar de la Paloma (The ring of the Dove). Madrid: Aliana Editorial, S.A.

Hazm, I. n.d. The Ring of the Dove. Islamic Philosophy Online. Accessed May 3, 2018. http://www.muslimphilosophy.com/hazm/dove/ringdove.html. 
Hazm, I. (1916). Los Caracteres y la Conducta, Tratado de Moral Práctica (Morals and Right Conduct in the Healing of Souls). Madrid: Imprenta Ibérica.

Hui, D. (2005). False alarm or real warning? Implications for China of Teaching English. Journal of Educational Enquiry, 6(1), pp.90-109.

Maley, A. (1986). XANDAU - 'A miracle of Rare Device': the Teaching of English in China. In J.M. Valdes (ed.), Culture Bound: Bridging the Cultural Gap in Language Teaching (pp.102-111). Cambridge: Cambridge University Press

Murray, D.M. (1982). The Great Wall of China. Today’s Education, 71, pp.55-58.

Lewis, B. (1993). The Arabs in History. Oxford: Oxford University Press.

Pennycook, A. (2013). The Cultural Politics of English as an International Language. New York: Routledge.

Prodromou, L. (1988). English as Cultural Action. The ELT Journal, 42(2), pp.73-83.

Reina, M. F. (2007). Poesía Andalusí (Andalusian Poetry). Madrid: Editorial EDAF, S.L.

Ryle, Robyn. (2012). Questioning Gender: A Sociological Exploration. Los Angeles: Sage Publications, Inc.

Sattar, H.A. (2002). Fundamentals of Classical Arabic. Chicago: Faquir Publications.

Spence, J.T. (1985). Achievement American Style: The Rewards and Cost of Individualism. American Psychologist Journal of the American Psychological Association, 40(12), pp.1285-1295.

Xu, Z.G. (1997). Interpretation of Analects. Beijing: People's Literature Press. 